\title{
Graduate Student Literature Review: The effects of bedding, stall length, and manger wall height on common outcome measures of dairy cow welfare in stall-based housing systems*
}

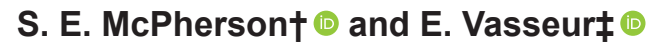 \\ Department of Animal Science, McGill University, Sainte-Anne-de-Bellevue, Quebec, H9X 3V9, Canada
}

\begin{abstract}
Understanding and improving dairy cow welfare in stall-based housing systems is an important issue for the dairy industry, and one area of the stall that has a large impact on cow welfare is the stall bed. The stall bed is defined both by its size and by the material components of the stall bed (bedding depth, bedding type, and stall base type). This review examines the current literature to determine how the material components of the stall bed, as well as bed length and manger wall/ brisket board height (which together define the length of the stall bed) can affect cow welfare through lying time, injuries, lameness, and cow and stall cleanliness. Of the material components of the stall bed, bedding depth appears to have the largest potential positive impact on dairy cow welfare, as deeper levels of bedding in stalls, regardless of the bedding type, can improve compressibility to the extent that the stall base type is negligible. As such, deeper levels of bedding have been associated with increased lying time and a reduced likelihood of a cow developing injuries or becoming lame. Longer stall bed lengths have been shown to increase lying time and decrease the prevalence of injury and lameness. The effect of manger wall or brisket board height on cow welfare has not been studied extensively, but they may work in conjunction with other stall components to define the resting space available to the cow. Overall, the material components of the stall bed, stall length, and manger wall/brisket board height, as well as their combination, all influence cow welfare and need to be taken in consideration to improve the overall welfare of cows in stall-based housing systems.
\end{abstract}

Key words: dairy cow, comfort, welfare, bedding, stall

Received February 7, 2020.

Accepted June 11, 2020.

*Submitted to the 2021 ADSA Foundation Graduate Student Literature Review Competition (Production, MS) on July 19, 2020.

†Corresponding author: sarahemcp@gmail.com

$\ddagger$ Advisor (elsa.vasseur@mcgill.ca).

\section{INTRODUCTION}

Stall-based housing systems are the most common indoor housing systems for dairy cattle; of these systems, tiestalls and freestalls are the most frequently found, with tiestalls accounting for 73 and $39 \%$ of farms in Canada and the United States, respectively (USDA, 2016; CDIC, 2020). With increasing societal concern for the welfare of dairy cattle, it is important that stallbased housing systems provide the cow with an environment that does not compromise her well-being. A cow's environment has a direct impact on her welfare status, thus the stall itself will play a role in determining the welfare status of the cow. Poor stall configurationwhen a cow does not "fit" well within the confines of the stall - can have a negative effect on a cow's welfare. Indicators of negative welfare status in stall-based housing systems typically include the prevalence of lameness and injuries to the hock, knee (carpal joints), and neck, as well as lying time and cow cleanliness. Similar issues can be seen in both types of stall-based housing systems. In tiestall systems, the prevalence of injuries to the hock, knee, and neck is 58, 44, and $33 \%$, respectively, in Canada (Bouffard et al., 2017). In freestall systems, the prevalence of injuries to the hock, knee, and neck is similarly high, affecting 47, 24, and $9 \%$, respectively, of Canadian freestall-housed cows (Zaffino Heyerhoff, et al., 2014), whereas in the United States, 57 to $81 \%$ of high-producing cows have been found to have hock injuries (Barrientos et al., 2013). Lameness is also prevalent in both tie- and freestall cows, affecting $25 \%$ of Canadian tiestall-housed cows (Bouffard et al., 2017), and $21 \%$ and $29 \%$ of Canadian and American freestall-housed cows, respectively (Ito et al., 2010; Solano et al., 2015). The physical structure of the stall is similar in freestall and tiestall systems, thus poor stall configuration will negatively affect cow welfare regardless of whether the stall is in a freestall or tiestall system.

In stall-based housing systems, the stall is used as the primary resting area for the cow; therefore, the bed of the stall will have a large effect on cow welfare. The stall 
bed can be defined by its size; that is, how much width and lengthwise space is accessible to the cow, as well as the material components, meaning the type of bedding, the depth of bedding, and the type of stall base. The amount of lengthwise space in the stall accessible to the cow is determined by the length of the stall bed, the height of the manger wall or brisket board, and the amount of manger space or lunge space in front of the stall bed. The configuration of the length and width of the stall, along with the types of materials chosen for the stall base, work together to form the stall bed and determine how comfortable the stall is for the cow.

The purpose of this review was to provide a systematic literature review on the individual effects that aspects of the stall bed have on common outcome measures of welfare, which have been reported in epidemiological and experimental studies performed on tiestall farms, freestall farms, or a combination of both stall-based housing systems. For the purpose of this review, only 3 aspects of the stall bed will be addressed: the material components of the stall bed, stall bed length, and manger wall/brisket board height.

\section{MATERIAL COMPONENTS OF THE STALL BED: BEDDING TYPE, BEDDING DEPTH, AND STALL BASE TYPE}

\section{Introduction to Bedding Type, Bedding Depth, and Stall Base Type}

The material components of the stall bed (bedding type, bedding depth and stall base type) work in combination to provide a comfortable resting surface for the cow by increasing compressibility and decreasing abrasiveness of the surface of the stall bed. An ideal stall bed should be soft, provide traction and thermal insulation for the cow, be easy to clean, and not be overly abrasive (Anderson, 2016). These goals are achievable through various combinations of bedding type, bedding depth, and stall bases. The stall base acts as the foundation at the bottom of the stall, upon which a variable amount of bedding is added. Often the type of stall base found on a farm will determine the type and depth of bedding used, but other farmand producer-driven variables also factor in, such as the availability of a bedding type in a given region or the pre-existing manure management system. Hard and abrasive stall bases, like concrete or hard rubber mats, require a greater depth of bedding than softer stall bases, like rubber- or gel-filled mattresses, but softer stall bases still require some bedding because they can be abrasive by themselves (Villettaz Robichaud et al., 2020). Thus, the combination of materials used on each farm depends on a variety of factors, but all bedding systems share the same goal of providing a comfortable resting surface for the cow. Supplying an ample amount of bedding is a best management practice in Canada and the United States for stall-based housing systems (NFACC, 2009; Dairyland Initiative, 2020). However, neither code of practice gives any specific requirements regarding the amount of bedding to be provided, as the minimum amount required varies depending on the type of bedding and the type of stall base.

The types of bedding and stall bases found on farms across North America vary according to the type of farm and location. On Canadian tiestall dairy farms, the most common stall bases are rubber mats and mattresses, representing about $51 \%$ and $44 \%$ of tiestalls, respectively, and they are most commonly bedded with straw (92\% of farms; Nash, et al., 2016). On Canadian freestall farms, the most prevalent stall bases are geotextile mattresses (56-60\% of farms; Zaffino Heyerhoff et al., 2014; Solano et al., 2015). There is less of a consensus on bedding material type, as shavings are the most commonly found type $(32-41 \%)$, followed by sawdust (24-30\%), straw (17-20\%), and sand (4\%; Zaffino Heyerhoff et al., 2014; Solano et al., 2015). Bedding systems in the United States vary depending on their location. Deep-bedded freestalls are the most prevalent in California ( $100 \%$ of sampled farms) and use dried or composted manure $(90 \%)$ or sand $(10 \%)$ as their bedding material (von Keyserlingk et al., 2012). In the northeastern United States, geotextile mattresses are the most common stall base and sawdust the most common bedding type, found on 48 and $35 \%$ of farms, respectively (von Keyserlingk et al., 2012). Bedding depth is not commonly reported in epidemiological studies in Canada or the United States, except in the case of deep-bedded stalls, but then the actual bedding depth is often not recorded.

Many producers are aware of the benefits of adding more bedding to their stalls, but the cost associated with that additional bedding often leads them to use a small amount. Traditional bedding materials, such as straw or wood shavings, are quite costly. Some research has explored cheaper alternatives to traditional North American bedding materials, and studies have mainly focused on indigenous perennial grasses that require low input to grow (van Weyenberg et al., 2015; Wolfe et al., 2018). Of these, switchgrass (Panicum virgatum), a high-yielding, long-term perennial grass that grows on marginal land, appears to be a suitable alternative bedding material; however, more studies are needed to determine the long-term effect of its use (Wolfe et al., 2018). If farmers are given the option of lower cost bedding, they will likely be inclined to provide more. 


\section{How Is Lying Time Affected by Bedding Depth, Bedding Type, and Stall Base Type?}

The amount of time that cows spend lying in a day can be influenced by barn type: cows have been found to spend $10.6 \pm 0.9 \mathrm{~h} / \mathrm{d}$ lying in freestall barns and $12.45 \pm 2.4 \mathrm{~h} / \mathrm{d}$ lying in tiestall barns (Nash et al., 2016; Solano et al., 2016). The overall comfort of the stall bed is a large factor in the lying behavior of cows in both tiestalls and freestalls. Bedding depth plays a large role in the lying behavior of dairy cows. By increasing the quantity of bedding experimentally, lying time has been shown to increase by 12 min for every additional $1 \mathrm{~kg}$ of straw and $3 \mathrm{~min}$ for every additional $1 \mathrm{~kg}$ of wood shavings added to the stall (Tucker et al., 2009). Cows on freestall farms across Canada with $>2$ $\mathrm{cm}$ of bedding, regardless of the bedding type, spent $+0.3 \mathrm{~h} / \mathrm{d}$ lying than cows housed in stalls with $<2 \mathrm{~cm}$ of bedding (Solano et al., 2016). The effect of increased bedding depth on lying bout duration and number of lying bouts per day is slightly less clear. Although Tucker et al. (2009) did not find that increasing the amount of straw or wood shavings in experimental stalls affected lying bout duration or number of lying bouts per day, Solano et al. (2016) found that Canadian cows housed in freestalls with $>2 \mathrm{~cm}$ of bedding lay down for 4 min longer per bout and had 0.4 bout/d fewer. When comparing deep-bedded stalls (i.e., $>20$ $\mathrm{cm}$ of bedding) with stalls having small amounts of bedding, the same trend was observed: cows on deepbedded stalls had fewer, longer lying bouts (Gomez and Cook, 2010). Although deep-bedding is most commonly seen with sand in freestall barns, deep-bedded tiestalls can be successful with other bedding materials, such as straw or shavings (Norring et al., 2008).

Several studies consider sand stalls to be a type of stall base, as they compare them to different stall bases (e.g., rubber mats, mattresses, concrete) with unknown quantities of bedding (i.e., Zaffino Heyerhoff et al., 2014; Solano et al., 2016). Although previous literature considers sand stalls to be a type of stall base, it is important to note that, technically, they are not. Rather, sand stalls are deep-bedded stalls with concrete (or another type of hard surface) at their stall base. In these cases, deep-bedded sand stalls may have been classified as their own category because the depth of bedding may have been the defining characteristic of these stalls.

There are mixed results regarding which stall base type is the most comfortable. Experimental studies have found that cows lie down for 0.7 to $1.2 \mathrm{~h} / \mathrm{d}$ more on rubber mats with minimal bedding compared with concrete with minimal bedding (Rushen et al., 2007; Norring et al., 2010). However, an epidemiological study by Solano et al. (2016) did not find any statistical difference between rubber mats, mattresses, and concrete stall bases, but did find that cows lay down 0.6 to 0.9 $\mathrm{h} / \mathrm{d}$ longer on deep-bedded sand stalls (Supplemental Table S1; https://doi.org/10.3168/jds.2020-18332). The same trends are reflected in the number of lying bouts cows have per day, with experimental studies finding that cows will have 1 to 3 bout/d more on rubber mats with a small amount of bedding compared with concrete with the same small amount of bedding (Rushen et al., 2007; Norring et al., 2010; Supplemental Table S1). In comparison, Solano et al. (2016) found that cows on concrete and deep-bedded sand will have 1 to 2 bout/d fewer compared with cows on mattresses or rubber mats. Overall, it appears that cows find concrete slightly less comfortable than mattresses or rubber mats, but that stall base type is negligible when more bedding is added.

Several confounding factors may have contributed to the inconsistency of the results in these epidemiological studies, the most obvious of which is that neither the quantity or quality of bedding on each of the stall bases was reported. A difference in the quantity (or depth) of bedding across the same stall base can influence lying time (Tucker et al., 2009), and thus may confound and be the cause for inconsistent results across epidemiological studies. For example, in studies where cows lay down on concrete stalls for longer compared with farms with mattresses, the farms with concrete stall bases may have compensated for the harder surface by using more bedding, and thus provided a more comfortable lying surface despite the harder and more abrasive stall base. Overall, it appears that cows will lie down for longer on stalls with softer, less abrasive stall bases than harder, more abrasive stall bases, but the influence of the abrasiveness or compressibility of the stall base itself appears to become negligible when more bedding is added to the stall. Thus, increasing the bedding depth appears to be the most important factor with respect to increasing cow comfort via lying time.

Bedding quality, which usually refers to bedding wetness, can also influence cow lying behavior: cows will spend longer lying in a dry stall and will modify their lying behavior in a wet stall. When experimentally changing moisture content in the bedding, cows lay down for 1 to $8 \mathrm{~h}$ more when on dry bedding ( $20 \%$ DM) compared with bedding with a higher moisture content (35-90\% DM; Fregonesi et al., 2007; Reich et al., 2010; Schütz et al., 2019). Lying on dry bedding also increased the number of lying bouts cows had per day and influenced lying bout duration (Ito et al., 2014; Schütz et al., 2019). Therefore, bedding quality can have a large impact on cow lying behavior, and poor bedding quality (i.e., a wet stall) may decrease lying 
time irrespective of bedding depth, bedding type, or stall base type present in the stall.

\section{How Are Hock and Knee Injuries Affected by Bedding Depth, Bedding Type, and Stall Base Type?}

Injuries are unfortunately relatively common on dairy farms, and many of the injured areas of the cow can be attributed to aspects of the material components of the stall bed. As cows can spend between 10 and $15 \mathrm{~h} / \mathrm{d}$ lying in stall-based barns, the material components of the stall bed have time to significantly affect the cow (Nash et al., 2016; Solano et al., 2016). Hocks, knees (carpal joints), and necks are the most commonly studied areas for injury prevalence on North American dairy farms, but neck injuries are more commonly associated with stall dimensions and physical aspects of the stall than with aspects relating to the material components of the stall bed (Bouffard et al., 2017; Jewell et al., 2019). Epidemiological studies have found that 56 and $42 \%$ of cows in tiestalls have injuries to the hock and knee, respectively, whereas 47 and $24 \%$ of cows in freestalls have injuries to the hock and knee, respectively (Zaffino Heyerhoff et al., 2014; Nash et al., 2016). The hock is considered the area most susceptible to the lying surface, because the cow places a lot of pressure on the hock when in a lying position, which may result in the hock having the highest injury prevalence. The carpal joints, commonly referred to as the (front) knees of the cow, are another area where injuries are often associated with the lying surface, although not to the same extent as the hocks. The knees bear weight while lying, but most injuries are attributed to impact with the stall bed during the normal lying-down motion (i.e., when the cow moves from a standing position into a lying position).

There are 2 main factors through which all 3 components of the stall bed (bedding type, bedding depth, and stall base type) influence the prevalence and likelihood of hock injuries: abrasiveness of the materials and compressibility of the surface. Different bedding materials, by nature, have different levels of abrasiveness. Cows on less abrasive bedding types, such as straw or sand, are $>50 \%$ less likely to develop a hock lesion compared with cows on wood shavings (Potterton et al., 2011; Jewell et al., 2019). Among stalls with small amounts of bedding, there is not much consensus as to whether concrete, mattresses, or rubber mats confer the lowest risk of a cow developing hock lesions, with some studies indicating that concrete leads to the most hock injuries and others rubber mats or mattresses (Kielland et al., 2009; Potterton et al., 2011; Zaffino Heyerhoff et al., 2014; Supplemental Table S1). Compressibility of the stall bed is partially determined by the stall base, but the depth of bedding can play an even greater role. When comparing stall base types, deep-bedded stalls clearly reduce the likelihood, by half or more, of cows having a hock injury compared with those with minimal bedding (Zaffino Heyerhoff et al., 2014; Jewell et al., 2019). On commercial farms, those with mattresses with minimal amounts of bedding have about $25 \%$ more cows with injured or swollen hocks than cows on farms with deep-bedded sand stalls (van Gastelen et al., 2011; Cook et al., 2016). Studies that have looked solely at the effect of bedding depth on hock injury prevalence find that cows are much less likely to have hock injuries if there is more than $1 \mathrm{~kg}$ of bedding in the stall (Kielland et al., 2009; Potterton et al., 2011). Thus, although all material components of the stall bed play a role in the prevalence and likelihood of a cow developing a hock injury, bedding depth appears to have the greatest effect.

The prevalence and likelihood of knee injuries also appears to be influenced by bedding type, bedding depth, and stall base type, but to a lesser extent than hock injuries. The compressibility of the stall base type may affect the prevalence of knee injuries, as cows housed in stalls with a concrete stall base are more likely to have a knee injury than those housed in stalls with rubber mats or mattresses (Rushen et al., 2007; Kielland et al., 2009). Bedding type, with its varying levels of abrasiveness, does not appear to affect the prevalence and likelihood of a cow developing a knee injury, as there is a lack of consensus as to what bedding type carries the lowest risk (Busato et al., 2000; Supplemental Table S1). The compressibility conferred by deeper levels of bedding may also play a role, but the recorded differences between deep-bedded stalls and those with minimal amounts of bedding are not large (i.e., 5 vs. $8 \%$ prevalence of knee injuries on farms with deep-bedded stalls vs. farms with mats or mattresses; Cook et al., 2016). Knee injuries are thought to be the result of the knees bearing weight during the lying-down motion; thus, the compressibility of the surface of the stall bed, through both stall base type and bedding depth, will likely affect knee injuries more than the level of abrasiveness of the bedding. However, other components of stall configuration, such as manger wall or brisket board height and stall length, may also affect knee injury prevalence.

\section{How Are Cow and Stall Cleanliness Affected by Bedding Depth, Bedding Type, and Stall Base Type?}

Stall and cow cleanliness are intrinsically linked in tiestall barns because the cow does not move from her 
stall. Cows are only free to lay down on the surface of their stall, thus the stall itself is the main source of contamination for the cow (i.e., urine or feces from her or her neighbors). In freestall barns, the cow is able to move around, thus factors external to the stall (i.e., lying in alleyways or legs splashed while walking) can contribute to her cleanliness status. However, in freestalls, cows have the option to not lie in a contaminated stall.

The overall prevalence of dirty cows is relatively low; the prevalence of dirty legs is around $13 \%$ in freestalls, and the prevalence of dirty legs, udders, and flanks is 4,4 , and $11 \%$, respectively, in tiestalls (Solano et al., 2015; Nash et al., 2016). Cows housed on sand stalls are often found to be dirtier (23.8 and $2.5 \%$ with hygiene score 3 and 4 , respectively) than cows on rubber-filled mattresses (15.2 and $0.4 \%$ with hygiene score 3 and 4 , respectively) or waterbeds (18.6 and $0.6 \%$ with hygiene score 3 and 4, respectively; Fulwider et al., 2007). However, these results may be skewed by the sand stalls being deep-bedded stalls, as cows on deep-bedded straw stalls were found to be dirtier than those on deep-bedded sand stalls (6.04 vs. 4.19 for straw vs. sand; Norring et al., 2008). Although deep-bedded stalls are often considered dirtier than those with minimal amounts of bedding, deep-bedding has been shown to reduce the likelihood of a cow having a dirty udder by half (de Vries et al., 2015) and decrease the prevalence of cows with dirty udders by $13 \%$ on farm (Cook et al., 2016). Based on the current research, there does not appear to be an obvious stall base that results in cleaner cows (Supplemental Table S1). The lack of consensus of the effect of stall base could be due to the studies not considering bedding depth and type when investigating the effect of stall base, along with other confounding factors related to the stall (e.g., cows in shorter stalls are less likely to have dirty udders; Bouffard et al., 2017) or the cleaning routine (e.g., farms that spend more time on stall maintenance have cows with less dirty teats; Plesch and Knierim, 2012). Despite common assumptions, there is not a widely reported link between bedding and stall cleanliness. Deep-bedded stalls are often viewed as dirtier than stalls with less bedding, but overall various studies have found there to be no difference or that there are more clean cows in deep-bedded stalls.

\section{How Is Lameness Affected by Bedding Depth, Bedding Type, and Stall Base Type?}

Lameness is a painful condition that can be the result of numerous factors and is costly to the producer. Low prevalence of lameness is often associated with a more comfortable environment for the cow; thus, stall com- fort, especially at the level of the stall bed, is important to consider in both freestall and tiestall barns. Research is largely unanimous regarding the link between stall bed comfort and lameness prevalence (van Gastelen et al., 2011; Supplemental Table S1). Farms with $>2 \mathrm{~cm}$ of bedding have a decreased likelihood of their cows developing lameness compared with farms with $\leq 2 \mathrm{~cm}$ of bedding, regardless of bedding type (Solano et al., 2015). Deep-bedded stalls, whether bedded with sand or another material, also further decrease the likelihood of a cow becoming lame compared with stall bases such as concrete with a minimal amount of bedding (Chapinal et al., 2013; Ito et al., 2014; de Vries et al., 2015). As such, bedding depth appears to be the most important factor at the stall base in terms of decreasing the likelihood and prevalence of lameness, because it increases the comfort of the bed and may influence other factors that contribute to lameness incidence, such as lying time and injuries.

\section{Summary}

Bedding depth appears to be the most influential material component of the stall bed, because it has the greatest ability to compensate for stall base type and bedding type if they are found to be abrasive or insufficiently compressible. Increasing bedding depth in the stall can increase lying time regardless of the stall base type or bedding type. Hock injuries are affected by bedding abrasiveness and compressibility, thus bedding depth (and stall base to a lesser extent) can play a large role in decreasing the likelihood of a cow developing hock injuries. Although there are no obvious bedding systems that result in cleaner cows, very little research has investigated the effect of bedding depth on cow cleanliness, and individual farmer management may play a significant role from farm to farm. Bedding depth is also a main factor in lameness prevalence, with increased depth decreasing the prevalence of lame cows on farm. As such, more dry, clean bedding promotes cow comfort and welfare in the stall. There does not appear to be a specific type of bedding or stall base for optimal welfare; producers should adapt their existing management to increase bedding depth, thus ensuring an optimal resting surface for the cow.

\section{BED LENGTH AND STALL LENGTH}

\section{Introduction to Bed Length and Stall Length in Stall-Based Housing Systems}

The length of the stall in part determines how much space the cow has to rest. The length of the stall bed can be described using 2 terms: stall length and bed 
length. Stall length is typically used to describe the total length of the stall; thus, its meaning differs between tiestalls and freestalls. In freestall barns, stall length refers to bed length plus the amount of lunge space, which is separated from the stall bed by the brisket board, if present. In tiestall barns, stall length is the same as bed length, because the manger space, which acts as the lunge space in tiestalls, is separated from the stall bed by the manger wall and is not considered part of the stall bed.

In Canada, the current recommendation for bed length in both freestalls and tiestalls is $1.2 \times$ the height of the cow's hip (Anderson, 2014, 2016). A ratio with hip height is used instead of measuring the imprint length of a cow, as nose-to-tail measurements are difficult to do and cow body size is relatively proportional. In the United States, recommendations for bed length vary and are based either on average hip height (Morabito and Bewley, 2020) or on average cow weight [i.e., small cow $(635 \mathrm{~kg})=178 \mathrm{~cm}(70$ in. $)$, medium cow $(726 \mathrm{~kg})=$ $183 \mathrm{~cm}$ (72 in.), large cows $(816 \mathrm{~kg})=193 \mathrm{~cm}$ (76 in.); Dairyland Initiative, 2020]. Regardless of the source, the goal of any stall bed length recommendation is to allow the cow enough length so that she may lie fully within the stall with her front legs tucked and her back legs and tail lying on the base of the stall (Anderson, $2014,2016)$. However, when provided with the opportunity to rest in a less restricted environment, such as a pen deep-bedded with straw, cows will use different, more extended lying postures than the narrower ones that the stall bed length recommendation is based on (i.e., tucked legs; Shepley et al., 2019; van Erp-van der Kooij et al., 2019). To adopt extended lying postures in a stall, cows have to either extend their legs over the top of the manger wall or brisket board or lie diagonally and extend their legs into an adjacent stall (Shepley et al., 2019). Longer stalls would allow cows to extend their front legs in the stall but are often not used due to producer concerns regarding cow and stall cleanliness and udder health.

Stall and bed lengths have been found to be fairly consistent across North America. In freestalls, mean stall bed length has been reported to be 178 and 177 $\mathrm{cm}$ in Canada and the United States, respectively, and mean stall lengths were 241 and $233 \mathrm{~cm}$ for Canada and the United States, respectively (von Keyserlingk et al., 2012; Zaffino Heyerhoff et al., 2014; Solano et al., 2015). Similar results were found for mean bed length in Canadian tiestalls $(178.1 \pm 8.5 \mathrm{~cm}$; Nash et al., 2016); however, these bed length results were slightly under what is recommended based on body size, falling at $1.19 \pm 0.06$ and $1.18 \pm 0.06$ for farms in Quebec and Ontario, respectively, instead of the $1.2 \times$ hip height recommendation (Bouffard et al., 2017). The size of the average cow on freestall farms in North America has not been recently reported, but it is likely to be similar to that of cows on Canadian tiestalls farms (150.6 \pm $4.25 \mathrm{~cm}$; Bouffard et al., 2017), and thus the average freestall bed length is slightly under recommendations at approximately $1.18 \pm 0.08$ times hip height. Although bed lengths are slightly under recommendations, they have increased slightly $(<1 \mathrm{~cm})$ in the past 10 to $15 \mathrm{yr}$ (Zurbrigg et al., 2005a). However, as cow size is also increasing, stall dimensions and farms should strive to meet the needs of the cows that inhabit them.

\section{How Is Lying Time Affected by Bed Length and Stall Length?}

Very few studies have investigated associations between bed length and lying behavior. Of those, a study conducted on 100 commercial tiestall farms found that cows in stalls shorter than recommended decreased their number of lying bouts per day by 0.325 for each $10-\mathrm{cm}$ reduction in length compared with the recommended bed length (Bouffard et al., 2017). Tucker et al. (2004) investigated the link between lying behavior and total stall length in an experimental setting in freestalls but, instead of changing bed length, tested 2 different lunge space lengths. They found that cows lay for 0.6 $\mathrm{h}$ longer in stalls with $109 \mathrm{~cm}$ of lunge space and 165 $\mathrm{cm}$ of bed length compared with stalls with $64 \mathrm{~cm}$ of lunge space and $165 \mathrm{~cm}$ of bed length, suggesting that the increased lunge space makes the stall more comfortable for rest. This result implies that lunge space and bed length should be considered in combination when investigating how cow rest differs between different freestall configurations. Overall, there is a relative lack of literature investigating or providing evidence for whether longer stalls increase lying time, but logically it makes sense when considered from a space availability perspective: a longer bed with more room is likely to provide more opportunity for different lying postures and thus be more comfortable. However, more research is required to fully determine the relationship between stall and bed length and lying time.

\section{How Are Hock and Knee Injuries Affected by Bed Length and Stall Length?}

The link between stall length and risk of injuries is not as obvious as other stall aspects, because length is not limited by a rail or another physical restriction, but the connection revolves around the total stall space available to the cow. Shorter stalls are more restrictive, reducing the total area of the stall. This, in turn, can affect cow ease of movement in her immediate environment and therefore affect cow comfort. Reducing the 
amount of space a cow has to move increases the likelihood that she comes into contact with the other, physical, confines of her stall while rising, lying, or making other movements. However, in recent years, the combination of producer concern for stall cleanliness and increasing average cow size has led to many stalls being shorter than recommended (Bouffard et al., 2017).

The length of the bed of the stall appears to play a role in the prevalence and risk of injuries to cows, specifically that shorter stall beds increase the risk for hock and knee injuries (Nash et al., 2016; Bouffard et al., 2017; Jewell et al., 2019; Supplemental Table S2; https://doi.org/10.3168/jds.2020-18332). However, it should be noted that there is a difference between the results for stall length and bed length in terms of injury prevalence. In an epidemiological study on freestall farms in the United Kingdom, Potterton et al. (2011) found contrasting results, with longer bed lengths decreasing the likelihood (odds ratios, OR) of hock swelling $(172-178 \mathrm{~cm}, \mathrm{OR}=1.00$ vs. $179-184$ $\mathrm{cm}, \mathrm{OR}=0.56$ ) but longer total stall lengths (longer lunge space) increasing the likelihood of hock hair loss $(184-218 \mathrm{~cm}, \mathrm{OR}=1.00$ vs. $233-271 \mathrm{~cm}, \mathrm{OR}=2.56)$. Interestingly, several studies have found that longer stall and bed lengths decrease the likelihood of hock injuries to a point, but then the likelihood of injury increases with very long lengths (Kielland et al., 2009; Potterton et al., 2011; Jewell et al., 2019). In these cases, other aspects of stall design, such as neck- or tie-rail position, brisket board or manger wall height and placement, and lunge space, should be considered because they may be the cause of the increased risk of injury. Thus, although bed length seems to affect cows in freestalls and tiestalls similarly, other aspects of stall design need to be considered in conjunction with bed length because it is not the only aspect of stall design that determines how much lengthwise space is available to the cow.

\section{How Is Lameness Affected by Bed Length and Stall Length?}

As previously mentioned, lameness is a complex issue with many proposed causations, but having too small a lying area, through either inadequate stall length or width, is associated with increased lameness prevalence (Rutherford et al., 2009). A few studies have indicated that increased stall length, whether through increased bed length or lunge space, decreases the likelihood of a cow being lame. However, others have not found stall length (bed or total) to be a factor associated with lameness prevalence in freestalls or tiestalls (Solano et al., 2015; Bouffard, 2016). In tiestalls, Zurbrigg et al. (2005b) found that the prevalence of normal hind claws increased $0.4 \%$ with each $2.54-\mathrm{cm}$ increase in bed length. The same trend has been seen in freestalls, with cows in stalls $>200 \mathrm{~cm}$ long having fewer occurrences of sole hemorrhages $(P<0.05)$ and heel erosion $(P$ $=0.06$ ) than cows in stalls $\leq 200 \mathrm{~cm}$ (Sogstad et al., 2005). Hoof health could be associated with lameness, and both may have a direct effect on locomotion scoring, through which lameness is often scored on farm. Increasing freestall length via the lunge space has also been shown to decrease the likelihood of a cow developing lameness; Faull et al. (1996) found that longer lunge spaces were linked to lower levels of lameness and lower locomotion scores, although the extent to which increased lunge space reduces lameness was not quantified. In addition, Dippel et al. (2009) concluded that cows were at a higher risk of being lame when they were in stalls that decreased their lying comfort, such as having a lunge space impediment (i.e., a manger wall $>30 \mathrm{~cm}$ or a restrictive neck-rail; $\mathrm{OR}=1.34$ in a stall with a lunge space impediment vs. $\mathrm{OR}=1.00$ without).

Insufficient stall length, whether through bed length or lunge space, may increase the likelihood of a cow being lame because it prevents proper cow ease of movement in the stall, particularly during rising or lying-down motions. Ceballos et al. (2004) found that cows need up to $300 \mathrm{~cm}$ of longitudinal space during the rising motion to lunge forward properly; thus, if a cow is provided inadequate space to rise properly, she may hurt herself by coming into contact with the confines of her stall. Although the link between lameness and stall and bed length has not been researched extensively, the hypothesis that decreased space in the stall may increase the likelihood of a cow being lame should be considered.

\section{How Are Cow and Stall Cleanliness Affected by Bed Length and Stall Length?}

One of the most obvious concerns of bed length for the producer is its effect on cow and stall cleanliness. Longer stalls are typically viewed as being dirtier than shorter stalls, but very few epidemiological studies have actually reported an association between stall cleanliness and stall or bed length on commercial farms (Ruud et al., 2011; Supplemental Table S2). The link between cow cleanliness and stall or bed length has been investigated more often: overall longer bed lengths increase the prevalence of dirty hind limbs by $2.04 \%$ and increase the prevalence of dirty udders by $3.56 \%$ for every $1-\mathrm{cm}$ increase in stall length (Zurbrigg et al., 2005b; Bouffard et al., 2017). The link between stall and cow cleanliness seems logical but is not clearly demonstrated in the literature. Plesch and Knierim (2012) investigated the link between stall cleanliness and teat cleanliness 
and found no association. However, they proposed that their results could have been influenced by several factors, including that producers may have spent extra time cleaning in preparation for the arrival of external people on their farm, thus influencing the results. Because the link between stall/bed length and cow and stall cleanliness is believed by producers and industry alike, more scientific evidence from both experimental and epidemiological studies is required.

\section{Summary}

Longer stalls decrease the risk of injury and increase lying time. Producers opt for shorter stalls to increase cow and stall cleanliness, and thus reduce the risk of udder health related diseases, but little scientific evidence is available to corroborate this decision. Because many dairy cows are housed in stalls that are too short for their body size (i.e., $>50 \%$ of cows in Canada; Bouffard et al., 2017), the decreased risk of having dirty cows on shorter stalls may not justify the welfare costs related to treating injured or lame cows or cows with reduced lying time.

\section{MANGER WALLS AND BRISKET BOARDS}

\section{Introduction to Manger Walls and Brisket Boards in Stall-Based Housing Systems}

Manger walls and brisket boards are analogous structures in tiestall and freestalls, respectively, that act as the front limit of the stall bed and thus are used to help the cow position herself in the stall, especially when resting. Lower manger walls or brisket boards allow cows easier access to the space directly in front of the stall, be it the manger or lunge space. Manger walls have an additional purpose in preventing mixing of bedding from the stall and feed from the manger. In tiestalls, manger walls represent the front of the stall and the front of the stall bed, whereas in freestalls, brisket boards separate the stall bed from the lunge space, and thus act only as the front limit of the stall bed, not the stall itself.

Manger walls and brisket boards may be analogous structures, but they can differ considerably in both material and construction. Manger walls in tiestalls are typically made of materials such as concrete or wood, and producers are advised to smooth out the corners of the manger wall on both the stall and manger sides (Anderson, 2014). Brisket boards are also recommended to have a rounded, smooth surface, but the variety of building materials varies more than manger walls. Wooden boards, concrete curbs, metal pipes, plastic curbs, or nylon straps can be used, although each have associated benefits and pitfalls (Anderson, 2016; Dairyland Initiative, 2020). A major characteristic where manger walls and brisket boards differ is in their recommended height. Recommendations for manger wall and brisket board height are the same in Canada and the United States. Manger wall height in tiestalls is recommended to be $20.32 \mathrm{~cm}$ (8 in.) from the top of the stall bed (i.e., from the top of the bedding surface, from what the cow stands upon) and it is recommended that manger walls be no higher than $30.48 \mathrm{~cm}$ (12 in.; Anderson, 2014; Dairyland Initiative, 2020). Manger walls are typically built around $15.24 \mathrm{~cm}$ (6 in.) wide because they are often part of the support for other parts of the stall, thus have to be sufficiently wide to support various posts (Anderson, 2014). In freestalls, brisket board height is recommended to be no higher than $10.16 \mathrm{~cm}$ (4 in.) from the stall bed (Anderson, 2016; Dairyland Initiative, 2020) and $10.16 \mathrm{~cm}$ (4 in.) wide (Anderson, 2016). However, some freestalls do not have a brisket board. The difference in size and variability in construction material is likely due to the brisket board not having to keep the bedding and feed separate, and thus it only has to position the cow in the stall. As such, the brisket board shows more variation in size and material.

In epidemiological studies on tiestall farms in Canada, the average manger wall height was found to be 20.4 $\mathrm{cm} \pm 8.5 \mathrm{~cm}$, but with a range from 0 to $39 \mathrm{~cm}$ (Nash et al., 2016). There were also provincial differences, with Ontario having slightly lower manger walls than Quebec $(19.2 \pm 6.6 \mathrm{~cm}$ vs. $21.3 \pm 9.2 \mathrm{~cm}$; Bouffard et al., 2017). In the Maritime provinces, $26 \%$ of farms had manger walls $<10 \mathrm{~cm}, 50 \%$ of farms had manger walls between 10 and $19 \mathrm{~cm}$, and $24 \%$ had manger walls $\geq 20$ cm high (Jewell et al., 2019). Brisket board height, or its presence or absence, is not as widely reported as manger wall height, but in the United States it was found to vary depending on location, with none of the freestalls sampled in California having a brisket board compared with $83 \%$ having them in the northeastern United States (von Keyserlingk et al., 2012). On Canadian freestall farms, brisket boards were found to be present on about $65 \%$ of farms and averaged 12 to 13 $\mathrm{cm}$ in height across Ontario, Alberta, and Quebec (Zaffino Heyerhoff et al., 2014; Solano et al., 2015).

\section{How Are Measures of Welfare Affected by the Height of Brisket Boards and Manger Walls?}

Neither brisket boards nor manger walls are well represented in terms of significant contributions in the scientific literature. Several epidemiological studies looking at injury prevalence on commercial farms did not find any association with brisket boards or manger 
walls (Kielland et al., 2009; Zaffino Heyerhoff et al., 2014; Nash et al., 2016; Supplemental Table S3; https: //doi.org/10.3168/jds.2020-18332). The few epidemiological studies that have found significant associations between outcome measures of welfare and brisket boards or manger walls have found that increased brisket board height is associated with a $5.7 \%$ increase in lameness prevalence (Espejo and Endres, 2007) and a $10-\mathrm{cm}$ decrease in manger wall height is associated with a 3.7\% increase in likelihood of a dirty udder (Bouffard et al., 2017). Interestingly, the epidemiological study by Jewell et al. (2019) found that manger walls of moderate height $(10-19 \mathrm{~cm})$ conferred the lowest risk for hock, knee, and neck injuries compared with a lower or higher manger wall.

Two experimental studies have investigated the effect of brisket boards or manger walls on dairy cow welfare. A study on brisket boards by Tucker et al. (2006) found that cows lying in freestalls without brisket boards changed their lying behavior. In addition, longer cows changed how they positioned themselves, lying farther forward in the stalls with no brisket boards when resting in a prone position (Tucker et al., 2006). Cows in freestalls without brisket boards increased their lying time by $1.2 \mathrm{~h} / \mathrm{d}$ and increased their lying bout length by $0.2 \mathrm{~h} /$ bout. In contrast, the experimental study by McPherson and Vasseur (2019) found that decreasing manger wall height (from 20 to $5 \mathrm{~cm}$ ) did not affect lying time, lying bout length, or lying bout duration. They also found evidence to suggest that cows lie more forward in the stall with a lower manger wall, but here it was to the detriment of the cow because it increased her contact with the tie-rail when rising (McPherson, 2020; S. E. McPherson and E. Vasseur, unpublished data).

It is possible that the relationship between height of the manger wall (or brisket board) and different behavior and welfare outcome measures is confounded by other aspects of stall design. Jewell et al. (2019) found that manger walls of medium height decreased the likelihood of injury, whereas those $<10 \mathrm{~cm}$ and $\geq 20 \mathrm{~cm}$ conferred a higher likelihood. Lower manger walls may decrease the risk of injury up to a point at which they no longer confer a benefit because the cow is restricted by another stall aspect.

\section{Summary}

Although manger walls and brisket boards define the front limit of the stall bed, it can also be defined by other aspects of stall design and construction, such as the material constituting the manger wall or brisket board (concrete or inflexible materials vs. softer or flex- ible materials) and the placement of other stall aspects such as the tie- or neck-rails. Therefore, the effect of lower manger walls or brisket boards may be minimal if other aspects of the stall are more restrictive.

\section{CONCLUSIONS}

In stall-based housing systems, different components of stall configuration can have large and varying effects on dairy cow welfare. Here we reviewed the literature to determine how the material components of the stall bed (bedding type, bedding depth, stall base type), as well as different stall lengths and manger wall or brisket board heights can affect cow welfare in stall-based housing systems through common outcome measures: lying time, injury prevalence, cow and stall cleanliness, and lameness. Of the material components of the stall bed, bedding depth appeared to be the most important, because increasing bedding depth, regardless of bedding type or stall base type, improved cow welfare through increased lying time and reduced injury prevalence. Longer stall bed lengths have been shown to decrease the prevalence and risk of injuries and lameness and increase resting times. Manger walls and brisket boards may influence how a cow positions herself in the stall when resting, but they have not been thoroughly evaluated, and may need to be assessed in combination with other stall design aspects. Considering the combination instead of the individual effects of different aspects of stall configuration may be beneficial to improve the overall welfare of cows in stall-based systems.

\section{ACKNOWLEDGMENTS}

The authors acknowledge the funding support of Novalait (Québec, QC, Canada), the Dairy Farmers of Canada (Ottawa, ON, Canada), and Lactanet (SainteAnne-de-Bellevue, QC, Canada) as part of Vasseur's Natural Sciences and Engineering Research Council (Ottawa, ON, Canada) Industrial Research Chair in the Sustainable Life of Dairy Cattle. The authors have not stated any conflicts of interest.

\section{REFERENCES}

Anderson, N. 2014. Dairy cow comfort: Tie-stall dimensions. Ontario Ministry of Agriculture, Food, and Rural Affairs (OMAFRA). Guelph, ON, Canada.

Anderson, N. 2016. Dairy cow comfort: Free-stall dimensions. Ontario Ministry of Agriculture, Food, and Rural Affairs (OMAFRA). Guelph, ON, Canada.

Barrientos, A. K., N. Chapinal, D. M. Weary, E. Galo, and M. A. G. von Keyserlingk. 2013. Herd-level risk factors for hock injuries in freestall-housed dairy cows in the northeastern United States and California. J. Dairy Sci. 96:3758-3765. https://doi.org/10.3168/ jds.2012-6389. 
Bouffard, V. 2016. Impact de la configuration des stalles sur le confort des vaches laitières en stabulation entravée. Université Laval, Québec, Canada.

Bouffard, V., A. M. de Passillé, J. Rushen, E. Vasseur, C. G. R. Nash, D. B. Haley, and D. Pellerin. 2017. Effect of following recommendations for tiestall configuration on neck and leg lesions, lameness, cleanliness, and lying time in dairy cows. J. Dairy Sci. 100:29352943. https://doi.org/10.3168/jds.2016-11842.

Busato, A., P. Trachsel, and J. W. Blum. 2000. Frequency of traumatic cow injuries in relation to housing systems in Swiss organic dairy herds. J. Vet. Med. A Physiol. Pathol. Clin. Med. 47:221-229. https://doi.org/10.1046/j.1439-0442.2000.00283.x.

CDIC (Canadian Dairy Information Centre). 2020. Dairy Barn Type in Canada. Accessed Apr. 17, 2020. https://www.dairyinfo.gc.ca/ eng/dairy-statistics-and-market-information/farm-statistics/dairy -barns-by-type/?id=1502467060775.

Ceballos, A., D. Sanderson, J. Rushen, and D. M. Weary. 2004. Improving stall design: Use of 3-D kinematics to measure space use by dairy cows when lying down. J. Dairy Sci. 87:2042-2050. https: //doi.org/10.3168/jds.S0022-0302(04)70022-3.

Chapinal, N., A. K. Barrientos, M. A. G. von Keyserlingk, E. Galo, and D. M. Weary. 2013. Herd-level risk factors for lameness in freestall farms in the northeastern United States and California. J. Dairy Sci. 96:318-328. https://doi.org/10.3168/jds.2012-5940.

Cook, N. B., J. P. Hess, M. R. Foy, T. B. Bennett, and R. L. Brotzman 2016. Management characteristics, lameness, and body injuries of dairy cattle housed in high-performance dairy herds in Wisconsin. J. Dairy Sci. 99:5879-5891. https://doi.org/10.3168/jds.2016 $-10956$.

Dairyland Initiative. 2020. Tiestall Design. Accessed May 3, 2020. https://thedairylandinitiative.vetmed.wisc.edu/home/housing -module/adult-cow-housing/tiestall-design/.

de Vries, M., E. A. M. Bokkers, C. G. van Reenen, B. Engel, G. van Schaik, T. Dijkstra, and I. J. M. de Boer. 2015. Housing and management factors associated with indicators of dairy cattle welfare. Prev. Vet. Med. 118:80-92. https://doi.org/10.1016/j.prevetmed .2014.11.016.

Dippel, S., M. Dolezal, C. Brenninkmeyer, J. Brinkmann, S. March, U. Knierim, and C. Winckler. 2009. Risk factors for lameness in freestall-housed dairy cows across two breeds, farming systems, and countries. J. Dairy Sci. 92:5476-5486. https://doi.org/10 $.3168 /$ jds.2009-2288.

Espejo, L. A., and M. I. Endres. 2007. Herd-level risk factors for lameness in high-producing Hlstein cows housed in freestall barns. J. Dairy Sci. 90:306-314. https://doi.org/10.3168/jds.S0022 -0302(07)72631-0.

Faull, W. B., J. W. Hughes, M. J. Clarkson, D. Y. Downham, F. J. Manson, J. B. Merritt, R. D. Murray, W. B. Russell, J. E. Sutherst, and W. R. Ward. 1996. Epidemiology of lameness in dairy cattle: Te influence of cubicles and indoor and outdoor walking surfaces. Vet. Rec. 139:130-136. https://doi.org/10.1136/vr.139.6.130.

Fregonesi, J. A., D. M. Veira, M. A. G. von Keyserlingk, and D. M. Weary. 2007. Effects of bedding quality on lying behavior of dairy cows. J. Dairy Sci. 90:5468-5472. https://doi.org/10.3168/jds.2007 -0494 .

Fulwider, W. K., T. Grandin, D. J. Garrick, T. E. Engle, W. D. Lamm, N. L. Dalsted, and B. E. Rollin. 2007. Influence of free-stall base on tarsal joint lesions and hygiene in dairy cows. J. Dairy Sci. 90:3559-3566. https://doi.org/10.3168/jds.2006-793.

Gomez, A., and N. B. Cook. 2010. Time budgets of lactating dairy cattle in commercial freestall herds. J. Dairy Sci. 93:5772-5781. https://doi.org/10.3168/jds.2010-3436.

Ito, K., N. Chapinal, D. M. Weary, and M. A. G. von Keyserlingk. 2014. Associations between herd-level factors and lying behavior of freestall-housed dairy cows. J. Dairy Sci. 97:2081-2089. https:/ /doi.org/10.3168/jds.2013-6861.

Ito, K., M. A. G. von Keyserlingk, S. J. LeBlanc, and D. M. Weary. 2010. Lying behavior as an indicator of lameness in dairy cows. J. Dairy Sci. 93:3553-3560. https://doi.org/10.3168/jds.2009-2951.

Jewell, M. T., M. Cameron, J. Spears, S. L. McKenna, M. S. Cockram, J. Sanchez, and G. P. Keefe. 2019. Prevalence of hock, knee, and neck skin lesions and associated risk factors in dairy herds in the Maritime Provinces of Canada. J. Dairy Sci. 102:3376-3391. https: //doi.org/10.3168/jds.2018-15080.

Kielland, C., L. E. Ruud, A. J. Zanella, and O. Østerås. 2009. Prevalence and risk factors for skin lesions on legs of dairy cattle housed in freestalls in Norway. J. Dairy Sci. 92:5487-5496. https://doi .org/10.3168/jds.2009-2293.

McPherson, S. 2020. Making stall beds more comfortable: The effect of longitudinal space and deep-bedding on the comfort and welfare of tie-stall-housed dairy cows. MS Thesis. Department of Animal Science, McGill University, Sainte-Anne-de-Bellevue, QC, Canada.

McPherson, S., and E. Vasseur. 2019. Making stall beds more comfortable: The effect of longitudinal space on lying behavior and leg injuries on dairy cows housed in deep-bedded tie-stalls. J. Dairy Sci. 102(Suppl. 1):51. (Abstr.)

Morabito, E., and J. Bewley. 2020. Tie-stall facilities: Design, dimensions, and cow comfort. Accessed May 3, 2020. https://afs.ca.uky .edu/dairy/tie-stall-facilities-design-dimensions-and-cow-comfort.

Nash, C. G. R., D. F. Kelton, T. J. DeVries, E. Vasseur, J. Coe, J. C. Z. Heyerhoff, V. Bouffard, D. Pellerin, J. Rushen, A. M. de Passillé, and D. B. Haley. 2016. Prevalence of and risk factors for hock and knee injuries on dairy cows in tiestall housing in Canada. J. Dairy Sci. 99:6494-6506. https://doi.org/10.3168/jds.2015-10676.

NFACC (National Farm Animal Care Council). 2009. Code of Practice: For the Care and Handling of Dairy Cattle. Dairy Farmers of Canada, Ottawa, ON, Canada.

Norring, M., E. Manninen, A. M. de Passillé, J. Rushen, L. Munksgaard, and H. Saloniemi. 2008. Effects of sand and straw bedding on the lying behavior, cleanliness, and hoof and hock injuries of dairy cows. J. Dairy Sci. 91:570-576. https://doi.org/10.3168/jds 2007-0452.

Norring, M., E. Manninen, A. M. de Passillé, J. Rushen, and H. Saloniemi. 2010. Preferences of dairy cows for three stall surface materials with small amounts of bedding. J. Dairy Sci. 93:70-74. https://doi.org/10.3168/jds.2009-2164.

Plesch, G., and U. Knierim. 2012. Effects of housing and management conditions on teat cleanliness of dairy cows in cubicle systems taking into account body dimensions of the cows. Animal 6:13601368. https://doi.org/10.1017/S1751731112000031.

Potterton, S. L., M. J. Green, J. Harris, K. M. Millar, H. R. Whay, and J. N. Huxley. 2011. Risk factors associated with hair loss, ulceration, and swelling at the hock in freestall-housed UK dairy herds. J. Dairy Sci. 94:2952-2963. https://doi.org/10.3168/jds .2010-4084.

Reich, L. J., D. M. Weary, D. M. Veira, and M. A. G. von Keyserlingk. 2010. Effects of sawdust bedding dry matter on lying behavior of dairy cows: A dose-dependent response. J. Dairy Sci. 93:15611565. https://doi.org/10.3168/jds.2009-2713.

Rushen, J., D. Haley, and A. M. de Passillé. 2007. Effect of softer flooring in tie stalls on resting behavior and leg injuries of lactating cows. J. Dairy Sci. 90:3647-3651. https://doi.org/10.3168/jds .2006-463.

Rutherford, K. M. D., F. M. Langford, M. C. Jack, L. Sherwood, A. B. Lawrence, and M. J. Haskell. 2009. Lameness prevalence and risk factors in organic and non-organic dairy herds in the United Kingdom. Vet. J. 180:95-105. https://doi.org/10.1016/j.tvjl.2008 .03 .015 .

Ruud, L. E., C. Kielland, O. Østerås, and K. E. Bøe. 2011. Free-stall cleanliness is affected by stall design. Livest. Sci. 135:265-273. https://doi.org/10.1016/j.livsci.2010.07.021.

Schütz, K. E., V. M. Cave, N. R. Cox, F. J. Huddart, and C. B. Tucker. 2019. Effects of 3 surface types on dairy cattle behavior, preference, and hygiene. J. Dairy Sci. 102:1530-1541. https://doi .org/10.3168/jds.2018-14792.

Shepley, E., G. Obinu, T. Bruneau, and E. Vasseur. 2019. Housing tiestall dairy cows in deep-bedded pens during an 8-week dry period: Effects on lying time, lying postures, and rising and lying-down behaviors. J. Dairy Sci. 102:6508-6517. https://doi.org/10.3168/ jds.2018-15859.

Sogstad, A. M., T. Fjeldaas, and O. Østerås. 2005. Lameness and claw lesions of the Norwegian Red dairy cattle housed in free stalls in 
relation to environment, parity and stage of lactation. Acta Vet. Scand. 46:203. https://doi.org/10.1186/1751-0147-46-203.

Solano, L., H. W. Barkema, E. A. Pajor, S. Mason, S. J. LeBlanc, C. G. R. Nash, D. B. Haley, D. Pellerin, J. Rushen, A. M. de Passillé, E. Vasseur, and K. Orsel. 2016. Associations between lying behavior and lameness in Canadian Holstein-Friesian cows housed in freestall barns. J. Dairy Sci. 99:2086-2101. https://doi.org/10 .3168/jds.2015-10336.

Solano, L.. H. W. Barkema, E. A. Pajor, S. Mason, S. J. LeBlanc, J. C. Zaffino Heyerhoff, C. G. R. Nash, D. B. Haley, E. Vasseur, D. Pellerin, J. Rushen, A. M. de Passillé, and K. Orsel. 2015. Prevalence of lameness and associated risk factors in Canadian HolsteinFriesian cows housed in freestall barns. J. Dairy Sci. 98:6978-6991. https://doi.org/10.3168/jds.2015-9652.

Tucker, C. B., D. M. Weary, and D. Fraser. 2004. Free-stall dimensions: Effects on preference and stall usage. J. Dairy Sci. 87:12081216. https://doi.org/10.3168/jds.S0022-0302(04)73271-3.

Tucker, C. B., D. M. Weary, M. A. G. von Keyserlingk, and K. A. Beauchemin. 2009. Cow comfort in tie-stalls: Increased depth of shavings or straw bedding increases lying time. J. Dairy Sci. 92:2684-2690. https://doi.org/10.3168/jds.2008-1926.

Tucker, C. B., G. Zdanowicz, and D. M. Weary. 2006. Brisket boards reduce freestall use. J. Dairy Sci. 89:2603-2607. https://doi.org/10 .3168/jds.S0022-0302(06)72337-2.

USDA. 2016. Dairy 2014: Dairy Cattle Management Practices in the United States, 2014. USDA, Fort Collins, CO.

van Erp-van der Kooij, E., O. Almalik, D. Cavestany, J. Roelofs, and F. van Eerdenburg. 2019. Lying postures of dairy cows in cubicles and on pasture. Animals (Basel) 9:183. https://doi.org/10.3390/ ani9040183.

van Gastelen, S., B. Westerlaan, D. J. Houwers, and F. J. C. M. van Eerdenburg. 2011. A study on cow comfort and risk for lameness and mastitis in relation to different types of bedding materials. J. Dairy Sci. 94:4878-4888. https://doi.org/10.3168/jds.2010-4019.

van Weyenberg, S., T. Ulens, K. De Reu, I. Zwertvaegher, P. Demeyer, and L. Pluym. 2015. Feasibility of Miscanthus as alternative bed- ding for dairy cows. Vet. Med. (Praha) 60:121-132. https://doi .org/10.17221/8059-VETMED.

Villettaz Robichaud, M., A. Pic, H. Delgado, S. Adam, R. Lacroix, D. Pellerin, and E. Vasseur. 2020. Short communication: Use of the Clegg hammer measure as an indicator of stall-surface compressibility in tie-stall housing and its relationship with stall comfort. J. Dairy Sci. 103:871-876. https://doi.org/10.3168/jds.2019-16308.

von Keyserlingk, M. A. G., A. Barrientos, K. Ito, E. Galo, and D. M. Weary. 2012. Benchmarking cow comfort on North American freestall dairies: Lameness, leg injuries, lying time, facility design, and management for high-producing Holstein dairy cows. J. Dairy Sci. 95:7399-7408. https://doi.org/10.3168/jds.2012-5807.

Wolfe, T., E. Vasseur, T. J. DeVries, and R. Bergeron. 2018. Effects of alternative deep bedding options on dairy cow preference, lying behavior, cleanliness, and teat end contamination. J. Dairy Sci. 101:530-536. https://doi.org/10.3168/jds.2016-12358.

Zaffino Heyerhoff, J. C., S. J. LeBlanc, T. J. DeVries, C. G. R. Nash J. Gibbons, K. Orsel, H. W. Barkema, L. Solano, J. Rushen, A. M. de Passillé, and D. B. Haley. 2014. Prevalence of and factors associated with hock, knee, and neck injuries on dairy cows in freestall housing in Canada. J. Dairy Sci. 97:173-184. https://doi .org/10.3168/jds.2012-6367.

Zurbrigg, K., D. Kelton, N. Anderson, and S. Millman. 2005a. Stall dimensions and the prevalence of lameness, injury, and cleanliness on 317 tie-stall dairy farms in Ontario. Can. Vet. J. 46:902-909.

Zurbrigg, K., D. Kelton, N. Anderson, and S. Millman. 2005b. Tiestall design and its relationship to lameness, injury, and cleanliness on 317 Ontario dairy farms. J. Dairy Sci. 88:3201-3210. https:// doi.org/10.3168/jds.S0022-0302(05)73003-4.

\section{ORCIDS}

S. E. McPherson (1) https://orcid.org/0000-0002-0385-0807

E. Vasseur (1) https://orcid.org/0000-0002-5087-6508 